\title{
STATE AID FOR ENVIRONMENTAL PROTECTION IN EU MEMBER STATES - THE PERSPECTIVE OF THE ECONOMIC GROWTH AND THE STATE OF PUBLIC FINANCE
}

\section{Abstract}

The article presents the conditions of admissibility of State aid in the European Union, taking into account the rules governing horizontal State aid. It offers an analysis of State aid granted by EU Member States is carried out under the provisions of the Treaty and the rules of State aid admissibility on the basis of regulations adopted by the European Commission in 2008 and 2014 on State aid provided under the framework for State aid for environmental protection. The analysis made it possible to verify the influence of State aid on economic growth and public finance in EU Member States which provided State aid for environmental protection in the years 2000-2015. The analysis was based on a linear regression model. The response variable (dependent variable $Y$ ) is: 1) the size of the GDP and 2) the size of general government sector debt, while the explanatory variable (independent variable $X$ ) is the expenditure on environmental aid.

Keywords: State aid, the European Union, environmental protection, economic growth, general government sector debt.

JEL Classification: E62, K20, K33.

\section{Introduction}

Basic regulations of the competition law governing State aid in the European Union can be found in articles 107, 108 and 109 of the Treaty on

Piotr Podsiadło, Cracow University of Economics, Faculty of Finance and Law, Department of Local Government Finance, Rakowicka 27, 31-510 Kraków, Poland, e-mail: podsiadp@uek.krakow.pl 
the Functioning of the European Union - TFEU (Consolidated Versions of the Treaty... 2012). Article 107 establishes the EU regulations regarding State aid admissibility. The provisions of article 107 par. 1 TFEU establish the principle of general prohibition of granting State aid while the provisions of par. 2 and 3 allow for granting State aid by way of exemption from the general prohibition (Podsiadło 2016a, 2016b). These exceptions are respectively the categories of aid which are admissible as compatible with the internal market (art. 107, par. 2) and the categories of aid which may be permitted, or may be considered compatible with the principles of the internal market (art. 107, par. 3). Article 108 defines the powers of the Council and the European Commission with regard to the aid granted by Member States and compliance with the provisions of article 107. In turn, article 109 gives the Council the power to issue regulations establishing rules for the application of articles 107 and 108.

On the basis of article 107 par. 3 (c) of the TFEU, the European Commission may consider compatible with the internal market State aid designed to facilitate the development of certain economic activities, where such aid does not adversely affect trading conditions to an extent contrary to the common interest. The primary objective of State aid control in the field of environmental protection is to ensure that aid measures will increase environmental protection above levels that would prevail were the aid not given and to ensure that the positive effects of the aid outweigh its negative effects in terms of distortions to competition, while taking account of the polluter pays principle ${ }^{1}$.

The purpose of this article is to analyse the State aid provided by EU Member States to finance environmental protection, specifically the aid's impact on economic growth and the general government sector debt of these

${ }^{1}$ Economic activities can harm the environment not least through pollution. In certain cases, in the absence of State intervention, enterprises can avoid bearing the full cost of the environmental harm arising from their activities. As a result, the market fails to allocate resources efficiently, since the negative external effects of production are not taken into account by the producer, but are borne by society as a whole. These negative externalities can be tackled by ensuring that the polluter pays for its pollution, which implies full internalisation of environmental costs by the polluter. In order to increase the level of environmental protection, Member States may want to use State aid to create incentives to achieve a higher level of environmental protection then required by the European Union standards or to increase the environmental protection in the absence of Union standards. They may also set national standards or environmental taxation at a higher level than required by Union legislation or they may use environmental taxation to implement the polluter pays principle unilaterally in the absence of Union legislation. 
countries. Economic growth is measured by the size of gross domestic product in real terms (GDP), a synthetic measure of the state's economic well-being. Moreover, the level of public debt of the general government sector is useful information not only in studying how sustainable public finance given the weight of burdens with service costs in the short term. The amount of public debt also shows the implementation of the redistribution-intergenerational function. Growing public debt in the current period may destabilise public finance for future generations.

For this article, the years 2000-2015 were adopted as the test period, i.e. the period in which the two most important development strategies - the Lisbon Strategy and the Europe 2020 Strategy - of the European Union were implemented ${ }^{2}$. It was posited that the amount of State aid provided by the EU Member States should be positively correlated with the size of the economic growth of these countries, and negatively correlated with the size of their general government sector debt. If GDP is positively correlated with the size of State aid for environmental protection, then positive economic growth among Member States occurs as State aid is increased. When the size of the general government sector debt is negatively correlated with the amount of State aid for environmental protection, then increasing that aid should prompt a decrease in the debt of the general government sector of Member States providing such aid.

\section{State Aid for Environmental Protection - Institutional and Legal Regulations}

The most common market failure in environmental protection is related to negative externalities. Negative externalities cause overproduction of the good in a competitive market, while positive externalities cause underproduction of the good in a competitive market, in both cases leading to a deadweight loss. Enterprises acting in their own interest have no incentive to take into account the negative externalities arising from production, neither when they decide on a particular production technology nor when they decide on production levels. Confronted with this market failure, the State tends to use regulation in order to ensure that the negative externalities arising from production are accounted for (Quigley 2009). Through the introduction of standards, taxation, economic instruments and other regulation, polluters have to pay

\footnotetext{
2 Taking the year 2015 as the closing period of observation was due to the available annual data on State aid, which is published by Eurostat.
} 
society for the cost of polluting in accordance with the polluter pays principle. Internalising these negative externalities consequently raises the private costs borne by those enterprises, thereby negatively affecting their revenue ${ }^{3}$.

In the absence of Union standards and market-based instruments fully reflecting the polluter pays principle, Member States may decide unilaterally to pursue a higher level of environmental protection. This may in turn create additional costs for the enterprises operating in their territory. For that reason, in addition to regulation, Member States may use State aid as a positive incentive to achieve higher levels of environmental protection. They can do this in two ways. First, Member States can create positive incentives for individual enterprises to go beyond Union standards. In this case, the beneficiaries of aid reduce pollution, because they receive aid to change their behaviour, and not because they have to pay for the costs of this pollution. The objective of State aid here is to address directly the market failure linked with the negative effects of pollution. Second, Member States can impose national regulation that goes beyond Union standards. However, this may strap certain enterprises with additional costs and thus affect their competitive conditions. In this case, State aid may be necessary to lessen the burden on the most affected enterprises and thereby enable Member States to adopt national environmental regulation that is stricter than Union standards.

The detailed criteria which the European Commission takes into account while evaluating the admissibility of aid have been defined in a number of normative acts and community soft law acts, which have no binding legal value on addressees (Chalmers et al. 2006). The Guidelines on State Aid for Environmental Protection and Energy 2014-2020 (2014) are based on the polluter pays principle, which article 191 par. 2 TFEU sets down as the foundation of the Union's environmental policy (Energy Taxation... 2016). A mere absence of internalised environmental costs should no longer be compensated. State aid should be approved if, on the one hand, it serves the objectives of environmental protection and follows the principles of environmental policy, such as the polluter pays principle; and on the other it does not unduly distort trade and competition among the Member States (Holmes 2004, 2006, Ezcurra 2014). The environmental aid guidelines trace

\footnotetext{
${ }^{3}$ Moreover, since the generation of pollution is unevenly spread among industries and enterprises, the cost of any environmentally friendly regulation tend to be differentiated, not only between enterprises, but also between Member States.
} 
the development of environmental policy in recent years as it pertains to the regulation of State aid ${ }^{4}$.

The environmental aid guidelines make clear how the Commission intends to exercise its discretion in the context of article 107 par. 3 (b) and (c) TFEU, and under what conditions it will deem aid for the benefit of environmental protection to be compatible with the internal market (Nicolaides \& Kleis 2014). The transparency the guidelines thus achieve enables Member States and undertakings to see what criteria the Commission will apply in reviewing the compatibility of State aid, and to adapt their behavior accordingly (Sanden 2014). The guidelines are limited to determining the eligibility of State aid to approval (Scott 2011). They expressly assume the presence of State aid within the meaning laid down in article 107 par. 1 TFEU, and refrain from making any statement interpreting that term ${ }^{5}$. The guidelines apply to State aid granted for environmental protection or energy objectives in all sectors governed by the Treaty. They therefore also apply to those sectors that are subject to specific Union rules on State aid - i.e. transport, coal, agriculture, forestry, and fisheries and aquaculture - unless such specific rules provide otherwise (Szydło 2015). In the guidelines, the Commission has identified a number of environmental and energy measures for which State aid under

${ }^{4}$ While the environmental aid guidelines of 1994 (Community Guidelines... 1994) still permitted aid for adjustment to existing standards as a temporary alternative solution, failing the complete internalisation of environmental costs, the guidelines of 2001 (Community Guidelines... 2001) limited such aid to SMEs. In the guidelines of 2008 (Community Guidelines... 2008) the Commission took the position that Member States may no longer compensate for the insufficient internalisation of environmental costs with State aid. As a result, aid for adaptation to existing or new standards is in general no longer permissible. What remains permissible is aid intended to provide undertakings with an incentive to undertake voluntary measures for the protection of the environment or to meet the stricter requirements of future environmental legislation sooner than legally mandated.

5 Of course, any statement made in a Union framework or Commission communication concerning interpretation of the concept of aid has a legal quality different from that of statements concerning an aid's eligibility for approval. The concept of state aid is determined by article 107 par. 1 TFEU in connection with the case law of the Union courts, while through publication of the conditions of eligibility for approval of aid, the Commission makes a commitment with respect to exercise of its broad discretion in reviewing the compatibility of certain aid with the internal market (Brown \& Kühling 2008). 
certain conditions may be compatible with the internal market under article 107 par. 3 (c) TFEU ${ }^{6}$.

With its decision to issue the general block exemption regulation (GBER) (Commission Regulation (EC) No 800/2008...2008, Commission Regulation (EC) No 651/2014...2014), the Commission for the first time made use of the possibility of exempting certain categories of environmental aid (European State Aid Law... 2010). This normative act has become a special measure unifying and simplifying existing rules on block exemptions and applied by cross-section to all instruments and sectors (Nyssens 2008). The unquestionable advantage of GBER regulation is that there is no obligation to report a proposed aid measure to the European Commission and likewise no need for a Member State to obtain a positive decision from the Commission (an authorisation) before a Member State undertakes to grant the State aid. As a result, the environmental aid guidelines apply to aid subject to notification under the GBER, as well as to other aid notified by the Member States and all illegal aid (Maillo 2017).

\section{Methodology of the Research}

Statistical analysis will be carried out based on two source tables.

Table 1 shows the calculations for the linear regression model concerning the slope parameter (directional factor $\beta)^{7} . t$ Stat is a test of the occurrence of a linear relationship between expenditures on State aid for environmental protection and the size of the GDP/general government sector debt.

6 These are: (1) aid for going beyond Union standards or increasing the level of environmental protection in the absence of Union standards (including aid for the acquisition of new transport vehicles), (2) aid for early adaptation to future Union standards, (3) aid for environmental studies, (4) aid for the remediation of contaminated sites, (5) aid for energy from renewable sources, (6) aid for energy efficiency measures, including cogeneration and district heating and district cooling, (7) aid for resource efficiency and, in particular, for waste management, (8) aid for $\mathrm{CO}_{2}$ capture, transport and storage including individual elements of the Carbon Capture Storage (CCS) chain, (9) aid in the form of reductions in or exemptions from environmental taxes, (10) aid in the form of reductions in funding support for electricity from renewable sources, (11) aid for energy infrastructure, (12) aid for generation adequacy measures, (13) aid in the form of tradable permits, (14) aid for the relocation of undertakings.

7 The factor $b$ of the regression function II is the estimator of the parameter $\beta$ of regression function I. The standard error $S b$ is the standard error of the estimator $b$ of the parameter $\beta$. The designations "Lower 95\%" and "Upper 95\%" concern lower and upper limits of so-called confidence interval of numerical values for parameter $\beta$, where this parameter is with a probability of $95 \%$. 
This statistical test makes it possible to verify the authenticity of the null hypothesis that the parameter of regression function I type $\beta$ is equal to zero, and the alternative hypothesis that it is not equal to zero $\left(\mathrm{H}_{0}: \beta=0 ; \mathrm{H}_{\mathrm{A}}\right.$ : $\beta \neq 0)$. The acceptance of the null hypothesis that parameter $\beta=0$ would mean that the increase in the value of expenditure on State aid by $€ 1$ million does not cause any changes in the size of the GDP/general government sector debt. This in turn means the lack of a relationship between expenditure on State aid and the size of the GDP/general government sector debt ${ }^{8}$. Given the perspective taken in this paper, it will be essential to reject the null hypothesis in favor of the alternative - that is, there is a significant statistical relationship between expenditure on State aid and the size of the GDP/ general government sector debt ${ }^{9}$. The $p$-value is the probability of making a type I error. This would involve, based on the results of the test, the rejection of the hypothesis that the value of parameter $\beta$ is zero, when in fact it is zero in the entire population ${ }^{10}$.

Table 2 contains regression statistics, including the correlation coefficient, determination coefficient, standard error and the parameters of the test $F$ that is, the value of test $F$ and the probability of making a type I error, when it is verified that expenditure on State aid does not impact the size of the GDP/ general government sector debt (the irrelevance of state aid expenditure in the regression model). Similar to the $t$-test described above, the test $F$ is used to test the significance of linear regression coefficient $\beta$ evaluation. Statistic $F$ with $F$-Snedecor distribution of $k_{1}$ and $k_{2}$ degrees of freedom is used to check this test. When rejecting the null hypothesis, $F>F_{\alpha}$ of no relation between expenditure on State aid and the size of the GDP/general government sector

${ }^{8}$ In other words, the acceptance of the null hypothesis means the lack of the influence of environmental aid provided by the Member States of the European Union on the size of their GDP/general government sector debt.

${ }^{9}$ From the tables of critical values of $t$-Student it is seen that $\pm t_{\frac{\alpha}{2}}= \pm 2.1448$ for $\alpha=$ 0.05 and $n-2=14$ degrees of freedom. The null hypothesis can be rejected in favour of the alternative hypothesis only when: $t_{b}<t_{\frac{\alpha}{2}}$ or $t_{b}>t_{\frac{\alpha}{2}}$, that is when $-t_{b}<-2.1448$ or $+t_{b}>+2.1448$.

${ }^{10}$ In other words, a type I error is a rejection of a real null hypothesis. The higher the value of the $t$-test means, the lower the probability of a type I error occurring. In general, it is assumed that if the $p$-value is less than 0.05 , the null hypothesis can be rejected in favour of the alternative hypothesis, and thus it can be claimed that there is a statistically significant relationship between the expenditure of EU Member States on state aid for environmental protection and the size of the GDP/general government sector debt of these countries. 
debt and accepting the alternative hypothesis of the existence of a statistically significant relationship between the variables ${ }^{11}$.

\section{Results}

The most important statistical test in the simple regression analysis is a test of whether the regression coefficient equals zero. If it can be concluded that the directional coefficient of the real regression line in the population equals zero, it will mean that there is no linear relation between expenditure on state aid and the size of GDP, or expenditure on State aid and the size of GDP are not linearly dependent. Therefore, there should be a test to determine the occurrence of the linear relation between expenditure on State aid for environmental protection in the Member States and the size of their GDP. Table 1 shows the statistics on this test.

Table 1. The Size of State Aid for Environmental Protection and the Size of GDP Analysis of Variance: the Line "Variable $X$ "

\begin{tabular}{l|c|c|c|c|c|c}
\hline $\begin{array}{c}\text { EU Member } \\
\text { State }\end{array}$ & $\begin{array}{c}\text { Regression } \\
\text { coefficient } \\
b\end{array}$ & $\begin{array}{c}\text { Standard } \\
\text { error } \\
\text { Sb }\end{array}$ & $\begin{array}{c}t \text { Stat } \\
t b\end{array}$ & $p$-value & $\begin{array}{c}\text { Lower } \\
95 \%\end{array}$ & $\begin{array}{c}\text { Upper } \\
95 \%\end{array}$ \\
\hline Austria & 96.89 & 10.60 & 9.1443 & $2.8 \mathrm{E}-07$ & 74.17 & 119.62 \\
\hline Belgium & 212.04 & 66.38 & 3.1942 & 0.0065 & 69.66 & 354.41 \\
\hline Bulgaria & 907.73 & 884.93 & 1.0258 & 0.3224 & -990.26 & $2,805.72$ \\
\hline Cyprus & 38.55 & 36.30 & 1.0619 & 0.3062 & -39.31 & 116.40 \\
\hline $\begin{array}{l}\text { The Czech } \\
\text { Republic }\end{array}$ & 134.24 & 74.69 & 1.7973 & 0.0939 & -25.95 & 294.44 \\
\hline Denmark & 11.67 & 25.99 & 0.4489 & 0.6604 & -44.08 & 67.42 \\
\hline Estonia & 53.12 & 18.61 & 2.8540 & 0.0127 & 13.20 & 93.04 \\
\hline Finland & 60.47 & 10.98 & 5.5080 & $7.7 \mathrm{E}-05$ & 36.92 & 84.01 \\
\hline France & 482.50 & 126.14 & 3.8251 & 0.0019 & 211.95 & 753.04 \\
\hline Germany & 20.80 & 6.94 & 2.9985 & 0.0096 & 5.92 & 35.68 \\
\hline Greece & 404.54 & 510.30 & 0.7927 & 0.4412 & -689.95 & $1,499.04$ \\
\hline Hungary & 265.74 & 164.44 & 1.6160 & 0.1284 & -86.96 & 618.44 \\
\hline Ireland & 607.76 & 166.66 & 3.6466 & 0.0026 & 250.30 & 965.22 \\
\hline Italy & $1,236.14$ & 842.36 & 1.4675 & 0.1644 & -570.54 & $3,042.81$ \\
\hline
\end{tabular}

11 From the table of critical values of the $F$-Snedecor for $k_{1}=1$ ( 1 independent variable) and $k_{2}=n-2=14$ degrees of freedom and $\alpha=0.05$ we read $F_{0.05}=4.60$. Thus, the alternative hypothesis can be adopted only when: $F>4.60$. 
Table $1 \mathrm{cnt} d$

\begin{tabular}{l|c|c|c|c|c|c}
\hline $\begin{array}{c}\text { EU Member } \\
\text { State }\end{array}$ & $\begin{array}{c}\text { Regression } \\
\text { coefficient } \\
b\end{array}$ & $\begin{array}{c}\text { Standard } \\
\text { error } \\
S b\end{array}$ & $\begin{array}{c}t \text { Stat } \\
t b\end{array}$ & $p$-value & $\begin{array}{c}\text { Lower } \\
95 \%\end{array}$ & $\begin{array}{c}\text { Upper } \\
95 \%\end{array}$ \\
\hline Latvia & 170.75 & 82.16 & 2.0783 & 0.0566 & -5.46 & 346.97 \\
\hline Lithuania & 192.95 & 82.98 & 2.3252 & 0.0356 & 14.97 & 370.92 \\
\hline Luxembourg & 255.84 & 63.40 & 4.0353 & 0.0012 & 119.86 & 391.82 \\
\hline The Netherlands & 232.29 & 19.37 & 11.9949 & $9.4 \mathrm{E}-09$ & 190.75 & 273.83 \\
\hline Poland & 163.43 & 59.02 & 2.7691 & 0.0151 & 36.85 & 290.02 \\
\hline Portugal & -293.09 & 1875.04 & -0.1563 & 0.8780 & -4314.65 & $3,728.47$ \\
\hline Romania & 105.29 & 31.71 & 3.3201 & 0.0051 & 37.27 & 173.31 \\
\hline Slovakia & 486.53 & 161.54 & 3.0117 & 0.0093 & 140.06 & 833.00 \\
\hline Slovenia & 60.73 & 23.74 & 2.5577 & 0.0228 & 9.80 & 111.65 \\
\hline Spain & 262.80 & 100.50 & 2.6148 & 0.0204 & 47.24 & 478.35 \\
\hline Sweden & 51.57 & 10.23 & 5.0419 & 0.0002 & 29.63 & 73.51 \\
\hline The United & 254.68 & 58.07 & 4.3860 & 0.0006 & 130.14 & 379.22 \\
Kingdom & 97.39 & 24.66 & 3.9495 & 0.0015 & 44.50 & 150.28 \\
\hline EU-28 &
\end{tabular}

Source: the author's own calculations.

Table 1 shows that for seventeen Member States - Austria, Belgium, Estonia, Finland, France, Germany, Ireland, Lithuania, Luxembourg, the Netherlands, Poland, Romania, Slovakia, Slovenia, Spain, Sweden and the United Kingdom - the regression coefficient takes a positive value, as it does at the level of the European Union (EU-28). Consequently, the increase in expenditure on State aid for environmental protection by $€ 1$ million is accompanied by an increase in GDP by an average of (by country): $€ 96.89$ million, $€ 212.04$ million, $€ 53.12$ million, $€ 60.47$ million, $€ 482.50$ million, $€ 20.80$ million, €607.76 million, €192.95 million, €255.84 million, €232.29 million, $€ 163.43$ million, $€ 105.29$ million, $€ 486.53$ million, $€ 60.73$ million, $€ 262.80$ million, $€ 51.57$ million and $€ 254.68$ million. At the level of the EU-28, the increase in the value of GDP is $€ 97.39$ million.

Bearing in mind, however, the confidence interval for the regression coefficient, it is nearly certain (95\% probability) that an increase in state aid of $€ 1$ million will cause GDP to rise in the following countries: Austria from $€ 74.18$ million to $€ 119.62$ million, Belgium from $€ 69.66$ million to $€ 354.41$ million, Estonia from $€ 13.20$ million to $€ 93.04$ million, Finland from $€ 36.92$ million to $€ 84.01$ million, France from $€ 211.95$ million to $€ 753.04$ million, Germany from $€ 5.92$ million to $€ 35.68$ million, Ireland 
from $€ 250.31$ million to $€ 965.22$ million, Lithuania from $€ 14.97$ million to $€ 370.92$ million, Luxembourg from $€ 119.86$ million to $€ 391.82$ million, the Netherlands from $€ 190.75$ million to $€ 273.83$ million, Poland from $€ 36.85$ million to $€ 290.02$ million, Romania from $€ 37.27$ million to $€ 173.31$ million, Slovakia from $€ 140.06$ million to $€ 833.00$ million, Slovenia from $€ 9.80$ million to $€ 111.65$ million, Spain from $€ 47.24$ million to $€ 478.35$ million, Sweden from $€ 29.63$ million to $€ 73.51$ million, the United Kingdom from $€ 130.14$ million to $€ 379.22$ million and at the overall EU-28 level from $€ 44.50$ million to $€ 150.28$ million.

It should also be noted that the probability of a type I error ( $p$-value), involving the rejection of a true null hypothesis that, in the case of these seven countries providing State aid for environmental protection does not significantly affect the size of the GDP of the countries, is below the accepted level of significance - that is, 0.05 . The consequence is that the result of the study in relation to these countries, may be considered important, and thus the null hypothesis can be rejected in favour of the alternative hypothesis.

The regression coefficient does not take negative values for any of the Member States, which means that the expenditure on State aid for environmental protection does not have a negative impact on these countries' GDP. Identical request as to the proposed hypothesis can be obtained by analysing the value of test $F(83.62,10.20,8.15,30.34,14.63,8.99,13.30,5.41$, $16.28,143.88,7.67,11.02,9.08,6.54,6.84,25.42,19.24$ and for EU-28: 15.60), and $F$ significance (the probability of type I error is less than 0.05 ). Table 2 shows the test $F$ parameters and regression statistics for the relationship between the amount of state aid for environmental protection and the value of GDP in the EU countries.

For both Austria and the Netherlands, there is a very strong and positive correlation between State aid for environmental protection granted to companies and the amount of the countries' GDP: 0.93 and 0.95 , respectively. These models have a very good fit to the empirical data, as their coefficient of determination comes out to 0.856584 and 0.911323 , also respectively. $85.66 \%$ and $91.13 \%$ of the variations in GDP in these countries were attributed to variations in expenditures on State aid for environmental protection, while the remaining $14.34 \%$ and $8.87 \%$ resulted from the impact of other factors. If the coefficient of determination takes values of less than 0.5 , the regression explains only less than $50 \%$ of the variation in GDP and predictions based on such a regression model may be unsuccessful because the model then explains very little. This means that predictions can be created based on the Austrian and Dutch models, because the regression model is characterised 
Table 2. State Aid for Environmental Protection and GDP - Regression Statistics and Test $F$

\begin{tabular}{|c|c|c|c|c|c|}
\hline \multirow[b]{2}{*}{$\begin{array}{c}\text { EU Member } \\
\text { State }\end{array}$} & \multicolumn{3}{|c|}{ Regression statistics } & \multicolumn{2}{|c|}{ Test $F$} \\
\hline & $\begin{array}{l}\text { Correlation } \\
\text { indicator }\end{array}$ & $\begin{array}{l}\text { Determi- } \\
\text { nation } \\
\text { coefficient }\end{array}$ & $\begin{array}{l}\text { Standard } \\
\text { error }\end{array}$ & $F$ & $\begin{array}{c}\text { Significance } \\
F\end{array}$ \\
\hline Austria & 0.9255 & 0.8566 & $16,344.61$ & 83.62 & $2.8 \mathrm{E}-07$ \\
\hline Belgium & 0.6493 & 0.4216 & $39,798.16$ & 10.20 & 0.0065 \\
\hline Bulgaria & 0.2644 & 0.0699 & $11,050.65$ & 1.05 & 0.3224 \\
\hline Cyprus & 0.2730 & 0.0745 & $3,053.17$ & 1.13 & 0.3062 \\
\hline $\begin{array}{l}\text { The Czech } \\
\text { Republic }\end{array}$ & 0.4330 & 0.1875 & $33,456.42$ & 3.23 & 0.0939 \\
\hline Denmark & 0.1191 & 0.0142 & $31,141.97$ & 0.20 & 0.6604 \\
\hline Estonia & 0.6065 & 0.3678 & $3,876.57$ & 8.15 & 0.0127 \\
\hline Finland & 0.8272 & 0.6842 & $13,986.96$ & 30.34 & $7.7 \mathrm{E}-05$ \\
\hline France & 0.7149 & 0.5110 & $164,368.30$ & 14.63 & 0.0019 \\
\hline Germany & 0.6254 & 0.3911 & $229,024.70$ & 8.99 & 0.0096 \\
\hline Greece & 0.2073 & 0.0430 & $30,674.75$ & 0.63 & 0.4412 \\
\hline Hungary & 0.3965 & 0.1572 & $16,416.52$ & 2.61 & 0.1284 \\
\hline Ireland & 0.6980 & 0.4871 & $25,243.34$ & 13.30 & 0.0026 \\
\hline Italy & 0.3651 & 0.1333 & $128,781.00$ & 2.15 & 0.1644 \\
\hline Latvia & 0.4856 & 0.2358 & $5,292.74$ & 4.32 & 0.0566 \\
\hline Lithuania & 0.5278 & 0.2786 & $7,489.98$ & 5.41 & 0.0356 \\
\hline Luxembourg & 0.7333 & 0.5377 & $6,680.93$ & 16.28 & 0.0012 \\
\hline The Netherlands & 0.9546 & 0.9113 & $22,943.17$ & 143.88 & $9.4 \mathrm{E}-09$ \\
\hline Poland & 0.5949 & 0.3539 & $72,320.74$ & 7.67 & 0.0151 \\
\hline Portugal & 0.0417 & 0.0017 & $17,408.37$ & 0.02 & 0.8780 \\
\hline Romania & 0.6637 & 0.4405 & $32,745.36$ & 11.02 & 0.0051 \\
\hline Slovakia & 0.6270 & 0.3932 & $16,721.29$ & 9.07 & 0.0093 \\
\hline Slovenia & 0.5643 & 0.3185 & $4,893.70$ & 6.54 & 0.0228 \\
\hline Spain & 0.5728 & 0.3281 & $131,043.20$ & 6.84 & 0.0204 \\
\hline Sweden & 0.8030 & 0.6449 & $37,977.47$ & 25.42 & 0.0002 \\
\hline $\begin{array}{l}\text { The United } \\
\text { Kingdom }\end{array}$ & 0.7608 & 0.5788 & $152,496.00$ & 19.24 & 0.0006 \\
\hline EU-28 & 0.7259 & 0.5270 & $1,076,201.00$ & 15.60 & 0.0015 \\
\hline
\end{tabular}

Source: the author's own calculations. 
by a very good fit and is not burdened much by the estimation error, which provides grounds for precise forecasting.

At $0.83,0.71,0.73,0.80$ and 0.76 , respectively, Finland, France, Luxembourg, Sweden and the United Kingdom all show a strong positive correlation between the amount of State aid provided and the level of GDP. However, the determination coefficients have a very low value -0.684245 , $0.511021,0.537709,0.644857$ and 0.578786 . For all of the countries of the European Union (EU-28) there is a strong positive correlation $(r=0.73)$ between the amount of State aid for environmental protection and GDP in real terms. The determination coefficient is 0.526999 .

In the case of Belgium, Estonia, Germany, Ireland, Lithuania, Poland, Romania, Slovakia, Slovenia and Spain, the values of the correlation coefficient are included in the interval $(0.53 ; 0.69)$. These countries demonstrated a weak and medium positive relationship between the amount of State aid they provided and GDP. Moreover, the regression line cannot be adjusted to the empirical data to a satisfactory degree. The determination coefficients for these countries are: $0.42,0.37,0.39,0.49,0.28,0.35,0.44,0.39$, 0.32 and 0.33 .

Table 3: State Aid for Environmental Protection and General Government Sector Debt - Analysis of Variance: the Line "Variable $X$ "

\begin{tabular}{l|c|c|c|c|c|c}
\hline $\begin{array}{c}\text { EU Member } \\
\text { State }\end{array}$ & $\begin{array}{c}\text { Regression } \\
\text { coefficient } \\
b\end{array}$ & $\begin{array}{c}\text { Standard } \\
\text { error } \\
\text { Sb }\end{array}$ & $\begin{array}{c}t \text { Stat } \\
t b\end{array}$ & $p$-value & $\begin{array}{c}\text { Lower } \\
95 \%\end{array}$ & $\begin{array}{c}\text { Upper } \\
95 \%\end{array}$ \\
\hline Austria & 123.42 & 12.55 & 9.8354 & $1.15 \mathrm{E}-07$ & 96.50 & 150.33 \\
\hline Belgium & 205.42 & 81.92 & 2.5076 & 0.0251 & 29.72 & 381.12 \\
\hline Bulgaria & 343.24 & 165.34 & 2.0759 & 0.0568 & -11.39 & 697.87 \\
\hline Cyprus & 172.77 & 28.25 & 6.1151 & $2.67 \mathrm{E}-05$ & 112.17 & 233.37 \\
\hline $\begin{array}{l}\text { The Czech } \\
\text { Republic }\end{array}$ & 103.62 & 37.27 & 2.7804 & 0.0147 & 23.69 & 183.55 \\
\hline Denmark & 16.80 & 13.18 & 1.2742 & 0.2233 & -11.48 & 45.07 \\
\hline Estonia & 9.38 & 1.92 & 4.8852 & 0.0002 & 5.26 & 13.50 \\
\hline Finland & 70.39 & 8.45 & 8.3326 & $8.5 \mathrm{E}-07$ & 52.27 & 88.50 \\
\hline France & $1,099.29$ & 158.07 & 6.9545 & $6.71 \mathrm{E}-06$ & 760.27 & $1,438.31$ \\
\hline Germany & 18.33 & 10.35 & 1.7705 & 0.0984 & -3.87 & 40.53 \\
\hline Greece & $1,549.54$ & $1,105.35$ & 1.4019 & 0.1827 & -821.20 & $3,920.27$ \\
\hline Hungary & 282.66 & 170.79 & 1.6550 & 0.1202 & -83.65 & 648.98 \\
\hline Ireland & $1,710.73$ & 216.84 & 7.8894 & $1.61 \mathrm{E}-06$ & $1,245.65$ & $2,175.80$ \\
\hline Italy & $1,644.64$ & $1,941.65$ & 0.8470 & 0.4112 & $-2,519.78$ & $5,809.07$ \\
\hline
\end{tabular}


Table 3 cnt'd

\begin{tabular}{l|c|c|c|c|c|c}
\hline $\begin{array}{c}\text { EU Member } \\
\text { State }\end{array}$ & $\begin{array}{c}\text { Regression } \\
\text { coefficient } \\
b\end{array}$ & $\begin{array}{c}\text { Standard } \\
\text { error } \\
S b\end{array}$ & $\begin{array}{c}t \text { Stat } \\
t b\end{array}$ & $p$-value & $\begin{array}{c}\text { Lower } \\
95 \%\end{array}$ & $\begin{array}{c}\text { Upper } \\
95 \%\end{array}$ \\
\hline Latvia & 158.94 & 39.67 & 4.0067 & 0.0013 & 73.86 & 244.02 \\
\hline Lithuania & 100.63 & 48.49 & 2.0755 & 0.0569 & -3.36 & 204.62 \\
\hline Luxembourg & 99.79 & 26.75 & 3.7304 & 0.0022 & 42.42 & 157.17 \\
\hline The Netherlands & 226.38 & 42.30 & 5.3513 & 0.0001 & 135.65 & 317.11 \\
\hline Poland & 85.67 & 39.06 & 2.1933 & 0.0457 & 1.90 & 169.45 \\
\hline Portugal & $3,682.55$ & $6,536.37$ & 0.5634 & 0.5820 & $-10,336.60$ & $17,701.66$ \\
\hline Romania & 66.88 & 8.39 & 7.9709 & $1.43 \mathrm{E}-06$ & 48.88 & 84.87 \\
\hline Slovakia & 176.69 & 106.90 & 1.6528 & 0.1206 & -52.60 & 405.98 \\
\hline Slovenia & 161.56 & 11.14 & 14.5019 & $7.95 \mathrm{E}-10$ & 137.67 & 185.45 \\
\hline Spain & 171.23 & 206.49 & 0.8293 & 0.4209 & -271.64 & 614.10 \\
\hline Sweden & 9.62 & 5.29 & 1.8164 & 0.0908 & -1.74 & 20.97 \\
\hline The United & 688.52 & 122.67 & 5.6129 & $6.4 \mathrm{E}-05$ & 425.42 & 951.61 \\
Kingdom & 155.86 & 37.82 & 4.1209 & 0.001039 & 74.74 & 236.98 \\
\hline EU-28 &
\end{tabular}

Source: the author's own calculations.

The calculations in Table 3 indicate that 15 Member States have a linear relationship between expenditure on state aid for environmental protection and the size of general government sector debt.

For Austria, Belgium, Cyprus, the Czech Republic, Estonia, Finland, France, Ireland, Latvia, Luxembourg, the Netherlands, Poland, Romania, Slovakia and the United Kingdom the regression coefficients take positive values. This means that expenditure on State aid for environmental protection has a positive impact on the state of public finance for these countries. This is true also at the level of the European Union (EU-28). An increase in expenditure on State aid by $€ 1$ million is accompanied by an increase in the size of general government sector debt, by an average of, respectively, $€ 123.42$ million, €205.42 million, €172.77 million, €103.62 million, €9.38 million, $€ 70.39$ million, $€ 1,099.29$ million, $€ 1,710.73$ million, $€ 158.94$ million, $€ 99.79$ million, €226.38 million, €85.67 million, €66.88 million, €161.56 million and $€ 688.52$ million. At the level of the EU-28, the value of general government sector debt increases by $€ 155.86$ million.

Taking into account the confidence interval for the regression coefficient, it is a near certainty ( $95 \%$ probability) that an increase in expenditure for State aid of $€ 1$ million will raise general government sector debt by the value 
of the interval ( $€ 96.50$ million; $€ 150.33$ million) for Austria, (€29.72 million; $€ 381.12$ million) for Belgium, (€112.17 million; €233.37 million) for Cyprus, ( $€ 23.69$ million; $€ 183.55$ million) for the Czech Republic, ( $€ 5.26$ million; $€ 13.50$ million) for Estonia, (€52.27 million; $€ 88.50$ million) for Finland, (€760.27 million; €1438.31 million) for France, (€1245.65 million; €2175.80 million) for Ireland, (€73.86 million; €244.02 million) for Latvia, (€42.42 million; €157.17 million) for Luxembourg, (€135.65 million; €317.11 million) for the Netherlands, ( $€ 1.90$ million; $€ 169.45$ million) for Poland, ( $€ 48.88$ million; $€ 84.87$ million) for Romania, ( $€ 137.67$ million; $€ 185.45$ million) for Slovenia, (€425.42 million; €951.61 million) for the United Kingdom and ( $€ 74.74$ million; $€ 236.98$ million) for the EU-28 overall. For these countries, the probability of making a type I error is very small, and does not exceed the accepted level of significance of 0.05 . Such an error would be connected with the rejection of a real null hypothesis concerning the lack of a correlation between the size of the State aid for environmental protection and the size of general government sector debt. Such a conclusion also applies to the EU-28 level.

Analysis of the value of the test $F$ (greater that 4.60) and $F$ significance (lower than 0.05 ) bears out the hypothesis. Table 4 lists the test $F$ parameters and regression statistics for the relationship between the size of State aid and the size of general government sector debt in EU countries.

Slovenia shows a very strong and positive correlation between State aid for environmental protection and the size of general government sector debt. The correlation indicator is 0.97 . With Slovenia's determination coefficient at 0.937585 , this model has a very good fit to the empirical data. $93.76 \%$ of the variations in the size of the government's general government sector debt were attributed to variations in expenditure on State aid, while the remaining $6.24 \%$ were the result of other factors (other non-aid variables, imprecise fit of a straight line to the empirical data).

Austria, Finland, Ireland and Romania also exhibit a very strong positive correlation between the amount of environmental aid they provide to undertakings and the size of general government sector debt (respectively, 0.93, 0.84, 0.92 and 0.89). However, the determination coefficient assumes lower values: $0.873571,0.832199,0.816374$ and 0.819437 .

Cyprus, Estonia, France, Latvia, the Netherlands and the United Kingdom likewise show a strong positive correlation (respectively 0.85 , $0.79,0.88,0.73,0.82$ and 0.83 ). For all six countries, there is a satisfactory adjustment of the regression line to the empirical data. For example, in the case of France, the coefficient of determination is 0.775518 . This means 
Table 4. State Aid for Environmental Protection and General Government Sector Debt - Regression Statistics and Test $F$

\begin{tabular}{|c|c|c|c|c|c|}
\hline \multirow[b]{2}{*}{$\begin{array}{c}\text { EU Member } \\
\text { State }\end{array}$} & \multicolumn{3}{|c|}{ Regression statistics } & \multicolumn{2}{|c|}{ Test $F$} \\
\hline & $\begin{array}{l}\text { Correlation } \\
\text { indicator }\end{array}$ & $\begin{array}{l}\text { Determi- } \\
\text { nation } \\
\text { coefficient }\end{array}$ & $\begin{array}{l}\text { Standard } \\
\text { error }\end{array}$ & $F$ & $\begin{array}{c}\text { Significance } \\
F\end{array}$ \\
\hline Austria & 0.9347 & 0.8736 & $19,356.04$ & 96.73 & $1.15 \mathrm{E}-07$ \\
\hline Belgium & 0.5567 & 0.3099 & $49,113.90$ & 6.29 & 0.0251 \\
\hline Bulgaria & 0.4851 & 0.2354 & $2,064.75$ & 4.31 & 0.0568 \\
\hline Cyprus & 0.8530 & 0.7276 & $2,376.37$ & 37.39 & $2.67 \mathrm{E}-05$ \\
\hline $\begin{array}{l}\text { The Czech } \\
\text { Republic }\end{array}$ & 0.5964 & 0.3557 & $16,693.41$ & 7.73 & 0.0147 \\
\hline Denmark & 0.3224 & 0.1039 & $15,794.24$ & 1.62 & 0.2233 \\
\hline Estonia & 0.7939 & 0.6303 & 399.92 & 23.86 & 0.0002 \\
\hline Finland & 0.9122 & 0.8322 & $10,762.81$ & 69.43 & $8.5 \mathrm{E}-07$ \\
\hline France & 0.8806 & 0.7755 & $205,971.50$ & 48.37 & $6.71 \mathrm{E}-06$ \\
\hline Germany & 0.4277 & 0.1829 & $341,708.80$ & 3.13 & 0.0984 \\
\hline Greece & 0.3508 & 0.1231 & $66,443.14$ & 1.97 & 0.1827 \\
\hline Hungary & 0.4045 & 0.1636 & $17,050.46$ & 2.74 & 0.1202 \\
\hline Ireland & 0.9035 & 0.8164 & $32,843.20$ & 62.24 & $1.61 \mathrm{E}-06$ \\
\hline Italy & 0.2208 & 0.0487 & $296,843.20$ & 0.72 & 0.4112 \\
\hline Latvia & 0.7309 & 0.5342 & $2,555.47$ & 16.05 & 0.0013 \\
\hline Lithuania & 0.4851 & 0.2353 & $4,376.40$ & 4.31 & 0.0569 \\
\hline Luxembourg & 0.7060 & 0.4985 & $2,818.90$ & 13.92 & 0.0022 \\
\hline The Netherlands & 0.8195 & 0.6716 & $50,118.37$ & 28.64 & 0.0001 \\
\hline Poland & 0.5057 & 0.2557 & $47,864.78$ & 4.81 & 0.0457 \\
\hline Portugal & 0.1489 & 0.0222 & $60,685.35$ & 0.32 & 0.5820 \\
\hline Romania & 0.9052 & 0.8194 & $8,663.40$ & 63.54 & $1.43 \mathrm{E}-06$ \\
\hline Slovakia & 0.4041 & 0.1633 & $11,065.83$ & 2.73 & 0.1206 \\
\hline Slovenia & 0.9683 & 0.9376 & $2,296.20$ & 210.31 & $7.95 \mathrm{E}-10$ \\
\hline Spain & 0.2164 & 0.0468 & $269,232.80$ & 0.69 & 0.4209 \\
\hline Sweden & 0.4367 & 0.1907 & $19,657.45$ & 3.30 & 0.0908 \\
\hline $\begin{array}{l}\text { The United } \\
\text { Kingdom }\end{array}$ & 0.8321 & 0.6923 & $322,150.30$ & 31.50 & $6.4 \mathrm{E}-05$ \\
\hline EU 28 & 0.7404 & 0.5481 & $1,650,645.00$ & 16.98 & 0.001039 \\
\hline
\end{tabular}

Source: the author's own calculations. 
that $77.55 \%$ of the variation in France's general government sector debt is attributed to the volatility of expenditure on State aid for environmental protection. The remaining $22.45 \%$ is the effect of random and non-random factors.

For Belgium, the Czech Republic, Luxembourg and Poland, the values of the correlation coefficient are included in the interval $(0.51 ; 0.71)$. These countries exhibit a weak and medium positive relationship occurring between the amount of State aid and the level of their general government sector debt. Moreover, the regression line cannot be satisfactorily adjusted to the empirical data. The determination coefficients for these countries are lower than 0.50 .

All EU countries (EU-28) exhibit a medium positive correlation (0.74) between the amount of State aid spent on the environment and the size of general government sector debt. This model has only a satisfactory fit to the empirical data, as its coefficient of determination is 0.548123 .

Given all of the above results, predictions can be created based on the Slovenian, Austrian, Finnish, Irish and Romanian models, because the regression model is characterised by a very good fit and is burdened by the estimation error to only a small extent. The grounds are therefore there for precise forecasting.

The regression coefficient did not take negative values for any of the Member States, which means that the expenditure on State aid for environmental protection does not have a negative impact on the size of general government sector debt in any of the EU Member States.

\section{Conclusions}

Regulation and market-based instruments are the most important tools to achieve environmental objectives. Soft instruments, such as voluntary eco-labels, and the diffusion of environmentally friendly technologies may also play an important role. However, even if finding the optimal mix of policy instruments can be complicated, the existence of market failures or political objectives does not automatically justify the use of State aid. According to the polluter pays principle, the polluter should pay all the costs of its pollution, including the indirect costs borne by society. Using State aid in this context would relieve the polluter of the burden of paying the cost of its pollution. State aid may therefore not be an appropriate instrument in such cases. However, the European Commission accepts that, in the context of an unsatisfactory level of environmental protection, State aid may provide 
positive incentives for enterprises to carry out activities or make investments which are not mandatory and would otherwise not be undertaken by profit-seeking companies.

The analysis of regression presented in this article indicates that expenditure on State aid for environmental protection and the size of the economic growth measured by GDP and the size of the general government sector debt are linearly dependent, respectively, regarding 17 and 15 Member States, which in the years 2000-2015 provided State aid for this purpose. The following regularities should also be noted:

1. For Austria, Belgium, the Czech Republic, Estonia, Finland, France, Ireland, Luxembourg, the Netherlands, Poland, Romania, Slovenia, the United Kingdom and the EU-28 level - there is a statistical basis for recognising the occurrence of a positive stochastic relation between both the size of economic growth (GDP) and the State aid for environmental protection and the size of the general government sector debt and State aid for environmental protection. This means that the increase in State aid leads to an increase in both GDP and national debt.

2. Germany, Lithuania, Slovakia, Spain and Sweden exhibit a stochastic relation between the size of GDP and State aid for environmental protection - a positive relation between the analysed variables. This means that the increase in environmental State aid to undertakings provided by these countries leads their economies to grow, while leaving their general government sector debt unaffected.

3. For Cyprus and Latvia there is a statistical basis for recognising the occurrence of positive stochastic relation between the size of the general government debt and State aid for environmental protection. This means that the increase in State aid leads to an increase in the size of the public debt, but does not affect the growth of their GDP.

\section{Discussion}

State fiscal policy and its consequences, particularly tax policy implemented within its frames (specifying the implementation of public revenue) and State aid policy (depending on the instruments of implementation - affecting both the expenditure and the revenue side of public finance sector), are closely linked with the real economy. The issue here is primarily about the relationship between the size of and changes in GDP, and changes in public funds. Changes in GDP affect changes in the revenue of the State budget and of other public funds - that is, the revenue of the entire general government 
sector. These correlations result from the fact that taxes and other public levies are part of GDP in revenue terms. Revenue generated in the process of creating GDP thus affect its consumption, but this correlation is non-linear, because part of the revenue is spent on monetary savings of individuals and entities operating in the economic system, mainly household savings. If these savings are to be transformed into demand for goods, especially goods for investment purpose, many factors will come into play, particularly the credit policy of banks or other financial system players whose function is to transform savings into capital provided to enterprises.

In the process of creating and distributing GDP, the State plays a crucial role: by taking, in the form of taxes and other public levies, some part of the revenue generated by households and enterprises, it changes the structure of aggregate demand in the economy. The taxes imposed on enterprises limit their investment opportunities, but revenues from taxes and other levies are directed by the State to both households (social assistance, unemployment benefits, scholarships etc.) and to enterprises (State aid in the form of grants), forming the basis of demand for consumer goods and investment goods.

State expenditure policy, which includes the policy of State aid to enterprises, can thus boost GDP growth and increase GDP per capita (which means the national economy is becoming more competitive) even if the State spends more money than it has accumulated in the budget. This portends the appearance of budget deficits, the accumulation of which in the coming years leads to the formation of general government sector debt. Deficits and the public debt that attends them are financed through domestic monetary savings or foreign ones. The State accomplishes this process by taking a loan in the form of debt securities, which are bought by banks, investment funds, insurance companies and the like - that is, institutions that accumulate the monetary savings of entities participating in the economy, mainly households. Fiscal policy therefore plays an important role in economic growth, especially when enterprises and commercial banks will not support real economic processes (investment processes) and economic growth (the refusal happens for various reasons, including an increased risk of capital loss is among them). The savings accumulated in commercial banks and other financial institutions are thus borrowed by the State, which creates the demand for consumer goods and investment goods, consequently stimulating the processes of economic growth.

The above outlined description of the relation between the real sphere and the fiscal sphere is necessarily greatly simplified. It provides a subject for theoretical investigation and empirical analysis, while econometric models, 
which aim to quantify these relations, combine them in a cause-and-effect structure. It is essential that these relations be ascertained with the analysis of such policy aid - concerning regional goals, sectoral and broadly understood horizontal goals - conducted within the framework of fiscal policy used by a given State or group of EU Member States. This analysis examines the relation between changes in fiscal policy (State aid policy) and changes in production and other real terms, and then in fiscal amounts (general government sector debt).

The regression analysis of State aid with horizontal objectives in environmental protection funding and the macroeconomic quantities indicated in the article contributes to comparative studies among countries conducting fiscal policy in the conditions of the single monetary policy and the countries outside of the euro area.

\section{Bibliography}

Brown, J. D. and Kühling, J. (2008) “Article 87 EC and the Community Courts: From Revolution to Evolution”. Common Market Law Review 45 (2): 465-98.

Chalmers, D., Hadjiemmanuil, C., Monti, G. and Tomkins, A. (2006) European Union Law: Text and Materials. Cambridge-New York: Cambridge University Press.

Commission Regulation (EC) No 800/2008 of 6 August 2008 Declaring Certain Categories of Aid Compatible with the Common Market in Application of Articles 87 and 88 of the Treaty (General Block Exemption Regulation) (2008), OJ L 214/3, 9.08.2008.

Commission Regulation (EU) No 651/2014 of 17 June 2014 Declaring Certain Categories of Aid Compatible with the Internal Market in Application of Articles 107 and 108 of the Treaty (2014), OJ L 187/1, 26.06.2014.

Community Guidelines on State Aid for Environmental Protection (1994), OJ C 72/3, 10.03.1994.

Community Guidelines on State Aid for Environmental Protection (2001), OJ C 37/3, 3.02.2001.

Community Guidelines on State Aid for Environmental Protection (2008), OJ C 82/1, 1.04.2008.

Consolidated Versions of the Treaty on the European Union and the Treaty on the Functioning of the European Union, OJ C 326, 26.10.2012.

Energy Taxation, Environmental Protection and State Aid. Tracing the Path from Divergence to Convergence (2016) eds P. Pistone, M. Ezcurra. Amsterdam: International Bureau of Fiscal Documentation.

European State Aid Law. Handbook (2010) ed. M. Heidenhain. München-Oxford: Verlag C.H. Beck, Hart Publishing.

Evans, A. (1997) European Community Law of State Aid. Oxford European Community Law Series. Oxford-New York: Oxford University Press. 
Ezcurra, M. V. (2014) "EU State Aid and Energy Policies as an Instrument of Environmental Protection: Current Stage and New Trends". European State Aid Law Quarterly 13 (4): 665-74.

Guidelines on State Aid for Environmental Protection and Energy 2014-2020 (2014) OJ C 200/1, 28.06.2014.

Holmes, S. (2004) “The Environmental Guidelines: Black Smoke or Sustainable Development? The Need for Reform”. European State Aid Law Quarterly 3 (1): 17-26, https://doi.org/10.21552/ESTAL/2004/1/33.

Holmes, S. (2006) "Environmental Aid: A Case for Fundamental Reform (2)". European State Aid Law Quarterly 5 (4), https://doi.org/10.21552/ESTAL/2006/4/91.

Maillo, J. (2017) "Balancing Environmental Protection, Competitiveness and Competition: A Critical Assessment of the GBER and the EEAG”. European State Aid Law Quarterly 16 (1): 4-10, https://doi.org/10.21552/estal/2017/1/4.

Nicolaides, P. and Kleis, M. (2014) "A Critical Analysis of Environmental Tax Reductions and Generation Adequacy Provisions in the EEAG 2014-2020". European State Aid Law Quarterly 13 (4): 636-49.

Nyssens, H. (2008) “The General Block Exemption Regulation (GBER): Bigger, Simpler and More Economic". Competition Policy Newsletter 3: 12-18.

Podsiadło, P. (2016a) "The Interference of Law and Economics: The Case of Guarantees for Bank Debt and Their Impact on the Competitiveness of the EU Member States". European State Aid Law Quarterly 15 (1): 72-90.

Podsiadło, P. (2016b) "State Aid and the Functioning of the Single European Market - The Crisis Perspective". Ekonomia i Prawo. Economics and Law 15 (3): 385-99, https://doi.org/10.12775/eip.2016.026.

Quigley, C. (2009) European State Aid Law and Policy. Oxford-Portland: Hart Publishing. Sanden, J. (2014) "The EEAG 2014-2020 and the Remediation of Contaminated Sites". European State Aid Law Quarterly 13 (4): 650-64.

Scott, J. (2011) "In Legal Limbo: Post-legislative Guidance as a Challenge for European Administrative Law". Common Market Law Review 48 (2): 329-55.

Szydło, M. (2015) "How to Reconcile National Support for Renewable Energy with Internal Market Obligations? The Task for EU Legislation after Alands Vindkraft and Essent". Common Market Law Review 52 (2): 489-510.

\section{Abstract}

\section{Pomoc publiczna na ochronę środowiska naturalnego w państwach członkowskich Unii Europejskiej w kontekście wzrostu gospodarczego i stanu finansów publicznych}

W artykule przedstawiono warunki dopuszczalności pomocy publicznej w Unii Europejskiej z uwzględnieniem zasad regulujących horyzontalną pomoc państwa. Zaprezentowano analizę pomocy publicznej udzielonej przez państwa członkowskie UE na podstawie postanowień Traktatu o funkcjonowaniu Unii Europejskiej i zasad dopuszczalności pomocy publicznej uregulowanych przyjętymi przez Komisję Europejską w 2008 i 2014 r. rozporządzeniami w sprawie pomocy publicznej udzielanej zgodnie 
z wytycznymi dotyczącymi pomocy państwa w zakresie ochrony środowiska. Analiza umożliwiła zweryfikowanie wpływu pomocy publicznej na wzrost gospodarczy i finanse publiczne w państwach członkowskich UE, które udzielały pomocy na ochronę środowiska w latach 2000-2015. Analiza została oparta na modelu regresji liniowej. Zmienna objaśniana (zmienna zależna $Y$ ) to: 1) wielkość PKB i 2) wielkość długu sektora instytucji rządowych i samorządowych, natomiast zmienną objaśniającą (zmienną niezależną $X)$ są wydatki na pomoc w zakresie ochrony środowiska.

Słowa kluczowe: pomoc publiczna, Unia Europejska, ochrona środowiska naturalnego, wzrost gospodarczy, zadłużenie sektora general government. 